\title{
ПРОБЛЕМА БЕЗРАБОТИЦЫ: ИННОВАЦИОННАЯ ТЕХНОЛОГИЯ ЕЕ РЕШЕНИЯ
}

\author{
Г. Г. Гарин \\ Московский гуманитарный университет
}

Аннотация: В статье предложена инновационная технология решения проблемы безработицы с помощью внедрения разработанного автором проекта «Трудоустройство: V2.0».

Ключевые слова: безработица; цифровые технологии; безработные; центр занятости населения

\section{THE ISSUE OF UNEMPLOYMENT: AN INNOVATIVE TECHNOLOGY TO SOLVE IT}

\author{
G. G. Garin \\ Moscow University for the Humanities
}

Abstract: The article proposes an innovative technology to solve the issue of unemployment through the implementation of the project «Employment: V2.0» developed by the author.

Keywords: unemployment; digital technologies; unemployed; employment center

Обеспечение занятости населения является одной из наиважнейших, первоочередных задач государства. Конституция РФ гарантирует добровольность труда, у граждан есть право работать, или не работать, выбирать объем, нагрузку и ритм труда. Международная организация труда (МОT) определяет государственную службу занятости основным институтом, содействующим регулированию рынка труда и решению проблем безработицы граждан, уровень безработицы в стране - это отражение состояния экономики государства и перспектив его дальнейшего развития.

Проблемам безработицы и занятости посвящены исследования А. И. Бексултановой (Бексултанова, 2016: Электр. ресурс), К. Г. Кязимовой (Кязимов, 2017), Е. Ю. Давыдовой, О. И. Безяевой (Давыдова, Безяева, 2014), А. Н. Деминым, И. Л. Поповой (Дёмин, Попова, 2000), Ю. В. Болтенковой, М. Г. Солнышкиной (Болтенкова, Солнышкина, 2012), 3. Т. Голен- 
кова, Е. Д. Игитханян, И. М. Орехова, Ю. В. Черевко (Голенкова и др., 2009), Е. М. Старобиной, И. Е. Кузьминой, Е. О. Гордиевской (Старобина, Кузьмина, Гордиевская, 2016).

В настоящее время в России растет, как показывают социологические исследования, количество безработных. В стране сегодня масса безработных граждан, о занятости которых нет официальных данных, или они неточны. Так, по данным Росстата, уровень безработицы в 2014 г. составлял $5,2 \%$, в 2015 г. - 5,6\%, в 2016 г. - 5,5\%, в 2017 г. - 5,1\% .

Опрос ВЦИОМ в октябре 2017 года показал, что реальное число безработных в два раза выше, чем в данных Росстата. Уровень безработицы в России равен 11\% (ВЦИОМ, Электр. ресурс). Отсутствие достоверной информации о реальном уровне безработицы, о численности безработных, которые не замотивированы к регистрации в центрах занятости населения, создает вероятность возникновения социальных и экономических проблем в государстве. Каждый второй безработный в России - это молодые люди в возрасте от 20 до 30 лет. Среди безработных в настоящий момент превалируют лица в возрасте от 20 до 34 лет, 48,7\% в общей безработице составляют лица этого возраста (Интерфакс, Электр. ресурс).

В настоящее время большая часть информации государственного управления переведена в цифровую форму. Виртуальное пространство стало неотъемлемой частью настоящего. На наш взгляд, вопрос времени, когда услуги центров занятости перейдут в цифровые технологии. Сегодня есть много сайтов по поиску вакансий (hh.ru, Superjob и т. д.). Организовав более оперативную и удобную взаимосвязь безработного и государственной организации, можно добиться уменьшения общей безработицы. У безработных сегодня нет доверия к этой организации, они ищут работу через интернет и знакомых. Нововведением на 2019 год является переезд центров занятости в офисы «Мои документы». Проект, предложенный автором, станет дополнением для решения исследуемой проблемы.

Рассмотрим структуру проекта.

Проблема - отсутствие современной эффективно работающей технологии помощи безработным.

Цель проекта - обеспечение оперативности в процессе поиска работы для уменьшения количества безработных.

Задачи проекта:

1. Качественное улучшение системы трудоустройства в РФ,

2. Представление в сети интернет государственного инструмента поддержки безработных, привлечение их к регистрации как безработных,

3. Разработка максимально удобной процедуры учета безработных, их 
переобучения и получения ими пособия по безработице.

Целевая группа - безработные граждане, ищущие работу впервые.

По масштабу проект федеральный.

По объекту воздействия - безработные граждане РФ.

По содержанию - социальная.

По степени новизны - модернизированная.

Реализация проекта «Трудоустройство: V2.0» включает нескольких этапов:

Этап 1.

Проведение модернизации сайта www.trudvsem.ru и мобильного приложения «Работа в России», дополнив их функционал. Сайт и мобильное приложение могут функционировать для соискателя в различных режимах: ищущему впервые рабочее место при регистрации будет предложено пройти психологический тест для профессиональной ориентации. Перечень вопросов теста нацелен на выявление качеств, навыков или проверки профессиональных знаний, учитывая тенденции рынка труда. При желании заполненный тест можно прикрепить к резюме, которое создается на этом же сайте или через мобильное приложение. Создание на сайте мануала по вопросам трудоустройства с рекомендациями как отвечать на вопросы при собеседовании, какими данными заполнять резюме.

Создание всеобщей базы данных трудоустройства населения по РФ. Внеся один раз свои данные, безработному не придётся больше тратить время в очереди и собирать необходимые документы. При переезде с трудоустройством также не будет технических проблем.

Расширение функционала компьютерных классов «Мои документы» с целью проведения дистанционного обучения, с выходом в интернет. Так как обучение осуществляется дистанционно, безработные могут столкнуться с проблемой - отсутствием возможности выхода в Интернет. Если безработный не имеет специальной техники (компьютер или смартфон), он может обратиться в ближайший офис «Мои документы» для переобучения.

Этап 2.

a) Создание «Единой рабочей карты» сберегательно-накопительного формата. В накопление идут 3,5\% от зарплаты. Например, если зарплата 30000 рублей, то в накопление будут зачислены 1050 баллов. Стоимость 1 балла = 1 руб. Списать баллы можно у партнеров, привлеченных государством. При утрате работы на карту начисляется пособие по безработице в автоматическом режиме.

b) Введение «Единой рабочей карты» для начисления заработной платы, выдаваемой в офисе «Мои документы» и непосредственно на рабочем 
месте. Карта будет зарегистрирована получателем. В случае утраты карты ее можно будет восстановить в офисах «Мои документы». На карту начисляется зарплата с вычетом налогов, и начисляются баллы в размере 3,5\%. Баллы исчисляются в эквиваленте один к одному с Российским рублем. Баллы можно будет списать у партнеров, привлеченных государством или на ЖКХ. Вся информация по карте будет в личном кабинете или в мобильном приложении.

Этап 3.

a) Рекламная компания в формате рекламного ролика, распространяемая по СМИ и Интернет. Включает в себя рекламу уже обновленного формата системы трудоустройства.

b) Создание рекламного ролика. Реклама будет освещать все преимущества данной системы. Сайт или приложение само подберёт наиболее подходящие курсы профессиональной переподготовки с учетом требований соискателя и его предпочтений, возможностей и интересов. Единая рабочая карта в дополнение к зарплате начислит бонусы, а при потере работы автоматически начислит пособие по безработице.

c) Рекламный ролик будет распространяться с помощью СМИ и интернета.

Данные этапы нацелены на улучшение ситуации с обеспечением трудовых мест и увеличению количества зарегистрированных соискателей работы в отделах трудоустройства, посредством обновления уже имеющихся инструментов помощи безработным. В схематической форме этапы представлены на схеме.

Критерий оценки эффективность проекта. Оценка эффективности проекта производится на основе сравнения количества занятых и безработных граждан до начала реализации проекта и по истечению года после окончания реализации проекта. Если число зарегистрированных граждан как безработных больше, а общий уровень безработицы уменьшен, и держится на отметках меньших, чем до реализации проекта, то проект можно считать эффективным.

Сроки реализации проекта. Проект начинает действовать с даты начало запуска проекта, рассчитан на один год. Если проект покажет свою эффективность по истечению этого времени, то его можно перевести в режим постоянного функционирования.

Финансирование будет производится на средства государственного бюджета.

Нормативно-правовое обоснование проекта. Данная программа осуществляется на основе Закона РФ от 19.04.1991 N 1032-1 (ред. от 29.07.2017) «0 занятости населения в Российской Федерации». 


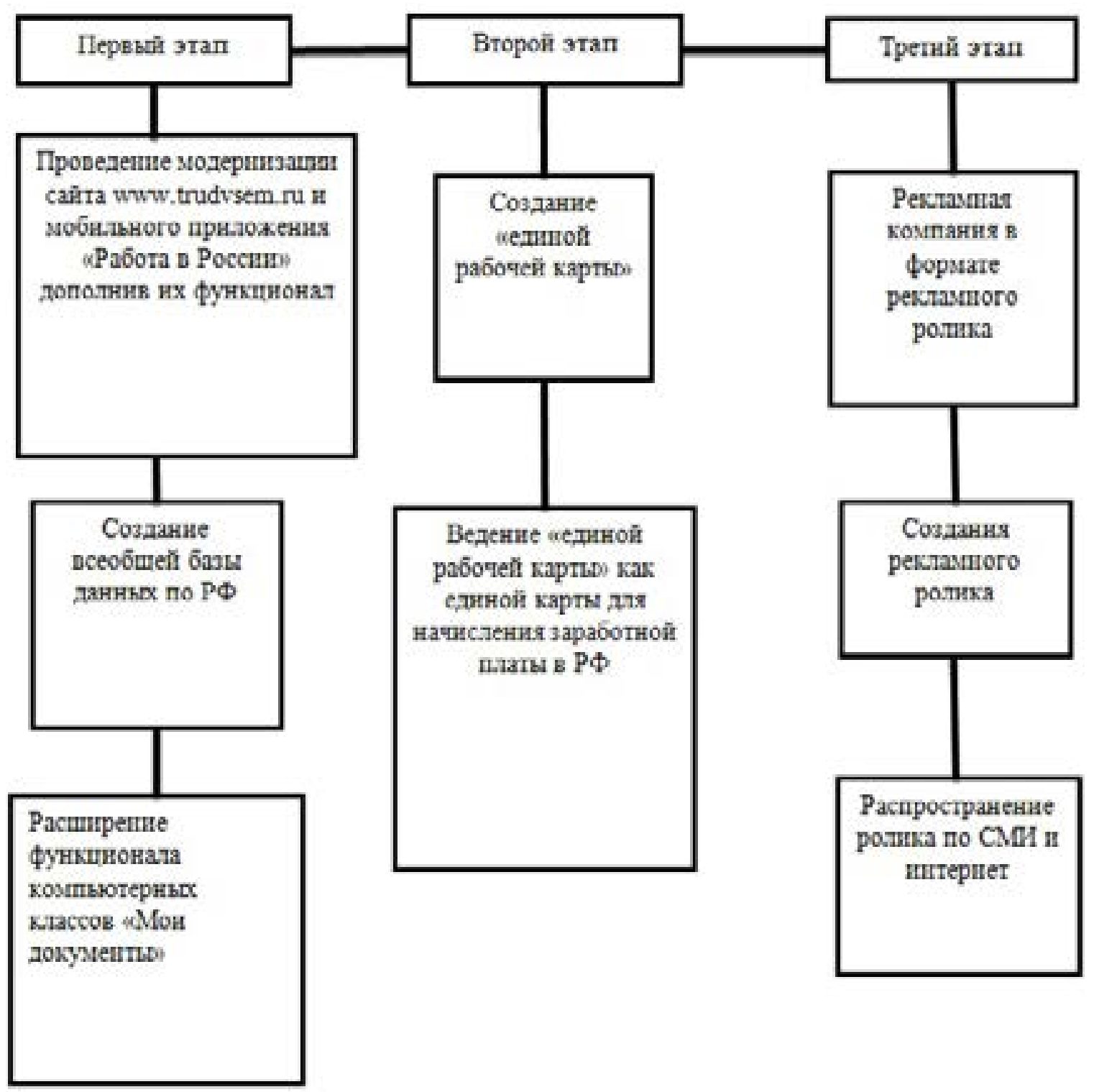

Схема. Алгоритм проектного решения

Ожидаемые результаты, достигаемые благодаря реализации проекта.

Уменьшение числа безработных и скрытых занятых, что приведет к более стабильной экономической и социальной ситуации в стране.

Риски проекта:

1. Недоверие со стороны потенциальных безработных,

2. Незаинтересованность сотрудников «Мои документы»,

3. Непринятие карты гражданами РФ как основного средства для получения заработной платы,

4. Возникновение технических проблем, связанных с работой сайта и приложения (сбой оборудования, сбой в работе сайта и приложения на программном уровне. 
Одной из острейших социально-экономических проблем российского населения в настоящие время является бедность.

Если по данным Росстата в 2012 г. за чертой бедности проживают 15,4 млн человек, то в 2018 г. количество бедняков составило 18,9 млн граждан или $12,9 \%$ от состава населения.

Среди многих причин бедности российских граждан эксперты сегодня на первое место ставят безработицу, повышение ее уровня.

По итогам исследования проблемы безработицы, нами сделаны следующие выводы:

1. Действующая в настоящие время в России государственная система по решению проблемы безработицы граждан, на наш взгляд, не является эффективной.

2. Применяемые сегодня центрами занятости населения технологии решения проблемы безработицы устарели, не отвечают современным требованиям. Они не учитывают прежде всего психологического состояния людей, оказавшихся в трудной жизненной ситуации. У сотрудников центров занятости совершенно отсутствует мотивация на эффективное выполнение своих обязанностей.

Исходя из вышеприведенных выводов, нами сформулирован ряд предложений:

1. Сложившаяся в настоящие время государственная система по решению проблемы безработицы российских граждан объективно нуждается в модернизации. С этой целью автором разработан социальный проект «Трудоустройство: V2.0», осуществление которого позволит на основе использования новых информационных технологий существенно повысить результативность работы государственных структур по решению сложнейшей социальной проблемы.

2. На наш взгляд, необходимо на государственном уровне организовать работу по систематическому обобщению опыта решения проблемы безработицы в регионах России. Автор выдвигает идею выпуска ежемесячного информационного бюллетеня: «Безработица: опыт решения проблемы в регионах России».

3. Усилению трудовой мотивации сотрудников центров занятости населения столицы способствовал бы регулярно проводимый городской конкурс на звание «Лучший центр занятости населения г. Москвы».

4. На наш взгляд, понятие «безработный» в сложившейся сегодня трактовке нуждается в критической оценке. Более точно, на наш взгляд, понятие «работоискатель». В этом случае словосочетание «работоискатель-работодатель» будет восприниматься совершенно-естественно и логично. 
Реализация вышеприведенных предложений будет способствовать, по нашему мнению, более эффективному решению проблемы безработицы российских граждан.

\section{СПИСОК ЛИТЕРАТУРЫ}

Бексултанова, А. И. (2016) Проблема безработицы в России и пути ее решения [Электронный ресурс] // Молодой ученый. № 1. C. 317-319. https:// moluch.ru/archive/105/24253/ (дата обращения:07.06.2019).

Болтенкова, Ю. В., Солнышкина, М. Г. (2012) Управление развитием региональной службы занятости населения. // Знание. Понимание. Умение. № 2. С. 138-141.

Голенкова, 3. Т., Игитханян, Е. Д., Орехова, И. М., Черевко Ю. В. (2009) Социальные характеристики трудовой занятости в регионе // Социологические исследования. № 9. С. 108-118.

Давыдова, Е. Ю., Безяева, О. И. (2014) Проблема безработицы в современной России // Территория науки. № 1. С. 75-79.

Дёмин, А. Н., Попова, И. П. (2000) Способы адаптации безработных в трудной жизненной ситуации // Социологические исследования. № 5. С. 35-46.

Кязимов, К. Г. (2017) Технологии регулирования рынка труда и занятости населения // Труд и социальные отношения. № 4. С. 3-10.

Старобина, Е. М., Кузьмина, И. Е., Гордиевская, Е. О. (2016) Социальная занятость инвалидов в системе антикризисных мероприятий в сфере занятости населения // Труд и социальные отношения. № 4. С. 39-54.

Дата поступления: 12.12.2019 2.

Гарин Герман Геннадьевич - студент факультета психологии, педагогики и социологии Московского гуманитарного университета. Адрес: 111395, Россия, г. Москва, ул. Юности, д. 5. Тел.: +7 (499) 374-60-21. Эл. адрес: garingerman@gmail.com

Garin German Gennadyevich, Student, Faculty of Psychology, Pedagogy and Sociology, Moscow University for the Humanities. Postal address: 5, Yunosti St., Moscow, Russian Federation, 111395. Tel.: +7 (499) 374-60-21. Email: garingerman@gmail.com

\section{Для цитирования:}

Гарин Г. Г. Проблема безработицы: инновационная технология ее решения [Электронный ресурс] // Научные труды Московского гуманитарного университета. 2019. № 6. URL: http://journals.mosgu.ru/trudy/article/view/1097 (дата обращения: дд.мм.гг.). DOI: $10.17805 /$ trudy.2019.6.6 